\title{
The research of the effect of oxidizing agents on the burning process of the carbon-containing component of ceramic masses and their firing properties
}

\author{
L.P. Shchukina (0000-0002-5817-4279), S.L. Lihezin (0000-0002-1097-1594), \\ M.I. Ryshchenko (0000-0001-9294-1761) \\ National Technical University "Kharkiv Polytechnic Institute», 2, Kirpichova St., Kharkiv, 61002, Ukraine \\ Tel.: +380577076482 \\ E-mail: milinvest@meta.ua
}

Article info: received 29.12.2019, revised 21.01.2020, accepted 20.02.2020

Shchukina, L.P., Lihezin, S.L., Ryshchenko, M.I. (2020) The research of the effect of oxidizing agents on the burning process of the carbon-containing component of ceramic masses and their firing properties 1(46), DOI: 10.26909/ csl.1.2020.3

The efficiency of using different oxidizing agents to intensify the burnout of the organic component of ceramic masses is investigated. The ceramic masses contained coal flotation wastes with a high carbon content as a fuel-mineral additive. Various inorganic salts, which are oxygen donors during the firing of ceramic masses and form oxidizing agents $\mathrm{O}_{2}, \mathrm{NO}_{2}, \mathrm{~N}_{2} \mathrm{O}$ during their thermal decomposition, are considered. A new calculation method for determining the content of an oxidizing salt in a ceramic mixture is proposed. This method takes as a basis the amount of «effective oxygen» that released during the thermal decomposition of the oxidizing agent, but not its mass, as it was before. The method allows calculating the rational content of an oxidizing agent necessary for efficient combustion of the carbon component of fuel-mineral additives. When calculating, it is necessary to take into the composition of the organic part of the additive, its content in the ceramic mass and the degree of carbon oxidation. Calculation of the rational content of the oxidizing agent according to this method allows avoiding its excessive and economically unreasonable use. The effect of oxidizing agents and their combinations on the burnout of the carbon component and the firing properties of the masses for wall ceramics is studied. The masses contained $15 \%$ of coal flotation waste with a carbon content of $29 \%$. It was found that the use of oxidizing agents accelerates the burnout of the organic part of the masses, improves the appearance and mechanical properties of ceramic samples. The use of combined oxidizing agents with different decomposition temperatures makes it possible to create an oxidizing medium in a wider temperature range. This positively effects on the mechanical properties of ceramics. The optimal combinations of oxidizing agents $\mathrm{NH}_{4} \mathrm{NO}_{3}+\mathrm{Ca}\left(\mathrm{NO}_{3}\right)_{2}$ and $\mathrm{NH}_{4} \mathrm{NO}_{3}+\mathrm{NaNO}_{3}$, which made it possible to obtain ceramic samples with a compressive strength $10 \mathrm{MPa}$, were determined. This mechanical strength meets the requirements of the State Standard of Ukraine B M.2.7-61: 2008 in part of ordinary brick of the M100 brand.

Key words: wall ceramics, coal flotation wastes, fuel-mineral additive, oxidizing agents, firing intensification.

\section{Дослідження впливу окисників на процес вигоряння вуглевмісного компонента керамічних мас та їх випалювальні властивості}

\author{
Л.П. Щукіна, С.Л. Лігезін, М.І. Рищенко
}

Національний технічний університет «Харківський політехнічний інститут», Харків, Украӥна

Досліджена ефективність використання різних окисників для інтенсифікації вигоряння органічного компоненту керамічних мас, що містили високовуглецеві відходи флотації вугілля як паливно-мінеральну добавку. Розглянуто ряд неорганічних солей, які є донорами кисню при випалі мас, і утворюють агенти-окисники $\left(\mathrm{O}_{2}, \mathrm{NO}_{2}, \mathrm{~N}_{2} \mathrm{O}\right)$ при ї термічному розкладі.

Запропонована нова розрахункова методика для визначення вмісту солі-окисника в керамічній шихті, яка бере за основу кількість «ефективного» кисню, що може бути виділена в результаті термічної обробки окисника, а не його масу, як це було раніше. Методика дозволяє розраховувати раціональну кількість будь-якого окисника, 
необхідну для ефективного вигоряння вуглецю паливно-мінеральної добавки з урахуванням речовинного складу органічної частини добавки, іiі вмісту в масі та заданого ступеня окиснення вуглецю. Визначення раціональної кількості окисника за даною методикою дозволяє уникнути його надмірного та економічно необгрунтованого використання.

Вивчено вплив окисників та їх комбінацій на процес вигоряння вуглецю у взаємозв’язку з випалювальними властивостями керамічних мас для стінової кераміки, що містили 15 \% відходів флотаційного збагачення кам'яного вугілля 3 вмістом вуглецю 29 \%. Встановлено, що використання окисників пришвидшує вигоряння органічної частини мас, покращує зовнішній вигляд і механічні властивості зразків. Застосування комбінованих окисників з різними температурами розкладу дозволяє створити окислювальне середовище у більш широкому температурному інтервалі при випалі, що позитивно впливає на механічні властивості кераміки. Визначені оптимальні комбінації окисників $\mathrm{NH}_{4} \mathrm{NO}_{3}+\mathrm{Ca}\left(\mathrm{NO}_{3}\right)_{2}$ i $\mathrm{NH}_{4} \mathrm{NO}_{3}+\mathrm{NaNO}_{3}$, які дозволили отримати керамічні зразки з межею міцності при стиску на рівні 10 МПа, що відповідає вимогам стандарту ДСТУ Б В.2.7-61:2008 на рядову цеглу марки М100.

\section{Вступ}

Важливою задачею керамічного сектору промисловості $є$ зниження енерговитрат, які складаються 3 витрат на електроенергію та паливо у співвідношенні майже 1:4 [1]. В Україні керамічні підприємства використовують переважно імпортний природний газ, що пояснює високий рівень виробничих енерговитрат та робить актуальним питання переорієнтації на власні первинні енергетичні ресурси.

У паливно-енергетичному балансі України єдиною енергетичною сировиною, запаси якої можуть задовольнити сьогоднішні внутрішні потреби й забезпечити потреби промисловості на багато років уперед, є вугілля. При цьому в структурі світових запасів вуглеводневої викопної сировини вугілля становить $67 \%$, нафта - $18 \%$ і газ - $15 \%$, а в Україні відповідно 94,5 \%, 2 \% і 3,6 \% [2]. Такий розподіл енергетичної сировини робить доцільним перехід керамічних підприємств, зокрема виробництв стінової кераміки, на твердопаливний вугільний випал, що можливо як в кільцевих, так і тунельних печах при застосуванні адаптованих систем згоряння палива. В напрямку запровадження таких систем на ринку обладнання працює відома іспанська компанія Beralmar, яка пропонує патентовані комплекси випалу з використанням вугілля, нафтового коксу, біомас або їх сумішей, які успішно функціонують в Свропі, Америці, Азії [3].

При використанні твердопаливного вугільного випалу також береться до уваги необхідність скорочення витрат палива, що можливо шляхом заміщення частини необхідного на випал вугілля паливно-мінеральною добавкою безпосередньо в керамічні маси. В цьому напрямку перспективним $\epsilon$ використання відходів вуглезбагачення - техногенного продукту, в якому вміст негорючих компонентів більш високий, ніж у чистого палива. Теплотворність відходів вуглезбагачення знаходиться в межах 4900 - 6700 ккал/кг. Залежно від сорту і гранулометричного складу вугілля, а також від способу отримання вуглевідходів та їх класу за крупністю, вміст вугілля в них змінюються в широких межах. Найбільша кількість вугілля (30 \% і навіть більше) знаходиться у відходах флотаційного способу збагачення [4]. У порівнянні з чистим вугіллям, яке можна також додавати в шихту, відходи флотації вигідно відрізняються більш дисперсним станом горючої маси і більш рівномірним іiі розподілом в шихті, що сприяє більш рівномірному прогріванню виробів в процесі випалу зсередини за рахунок вигорання внесеного паливом вуглецю, що в свою чергу знижує витрати первинного енергоносія.

В той же час при використанні відходів вуглезбагачення, особливо високовуглецевих, існує проблема зниження продуктивності печі за причини збільшення тривалості випалу, що викликано необхідністю повного згоряння органічної частини відходів. Скорочення тривалості випалу паливовмісних мас можна досягти шляхом додаткового введення речовин, які розкладаються з виділенням кисню в процесі їх нагріву (окисники) [5]. Кисень сприяє більш повному та інтенсивному протіканню термохімічних реакцій горіння органічної складової маси, що пришвидшує прогрів напівфабрикату і дозволяє інтенсифікувати процес випалу.

Метою даної роботи було визначення ефективності використання різних окисників як інтенсифікаторів вигоряння органічної частини паливовмісних мас для виробництва стінової кераміки.

\section{Матеріали та методи досліджень}

При проведенні експериментальних досліджень як глинисту сировину було використано легкотопкий пилуватий суглинок, що відноситься до родовища, яке експлуатується підприємством 3 виробництва рядової цегли (ПАП «Дзвін», Тернопільська обл.). Суглинок характеризується помірною пластичністю, але за числом пластичності $(9,0)$ набли- 
жається до малопластичних порід, що вказує на доцільність застосування технології напівсухого пресування напівфабрикатів. Суглинок спікається до водопоглинання 9,3\% за температури $950{ }^{\circ} \mathrm{C} 3$ отриманням керамічних зразків з межею міцності при стиску 20 МПа.

Як вуглецьвмісну сировину було використано відходи флотаційного збагачення кам'яного вугілля (м. Кам'янське, Дніпропетровська область), які відносяться до першого класу радіаційної безпеки і можуть використовуватися без обмежень. За елементним складом відходи є високовуглецевими (вміст вуглецю 29 \%) і мають температурний інтервал вигоряння вуглецю $500-1000{ }^{\circ} \mathrm{C}$. За показниками випалювальних властивостей відходи практично не спікаються, з їх використанням в чистому вигляді за температури $920^{\circ} \mathrm{C}$ отримано зразки з водопоглинанням 67,6 \% і механічною міцністю при стиску 2,9 МПа.

Як окисники були використані неорганічні солі $\mathrm{NaNO}_{3}, \mathrm{KNO}_{3}, \mathrm{Ca}\left(\mathrm{NO}_{3}\right)_{2}, \mathrm{Fe}\left(\mathrm{NO}_{3}\right)_{3}, \mathrm{NH}_{4} \mathrm{NO}_{3}, \mathrm{~K}_{2} \mathrm{Cr}_{2} \mathrm{O}_{7}$, що використовувались у вигляді розчинів і вводилися в масу з водою зачинення. Експериментальні зразки виготовлялись за наступною методикою. Відходи збагачення вугілля і суглинок висушували до повітряно-сухого стану і подрібнювали до повного проходження крізь сита № 05 і № 2 відповідно. При отриманні шихт компоненти змішувалися у сухому вигляді, а потім порошок зачиняли розчином солі-окисника до формувальної вологості $9 \%$. Зразки отримували способом напівсухого пресування у вигляді кубів та паралелепіпедів. Для випалу зразків використовувалась лабораторна муфельна піч СНОЛ 45/1300.

Дослідження відходів вуглезбагачення на предмет їхньої радіаційної безпеки проводилися 3 використанням гамма-спектрометричного аналізу на сцинтиляційному гамма-спектрометрі СЕГ-001 «АКПОС» (ГОСТ 30108-94). Клас радіаційної безпеки вуглевідходів встановлювали за класифікацією ДБН В.1.4-1.01-97 [6]. Речовинний склад відходів (вміст вуглецю, водню, кисню та сірки) визначали за методикою, що передбачає спалювання порошку в струмені кисню за температури $1250{ }^{\circ} \mathrm{C}$ ( ГОСТ 2408.1-95).

Мінеральний склад відходів вуглезбагачення визначався методом рентгенофазового аналізу з використанням дифрактометру ДРОН-3М з СuК $\alpha$ - випромінюванням та нікелевим фільтром. Термічний аналіз відходів проводили 3 використанням синхронного термічного аналізатора STA 409 PC.

Дослідження технологічних властивостей суглинку, відходів та продуктів випалу шихт проводили $з$ використанням методів випробувань, визначених ГОСТ 21216-93.

\section{Результати та їх обговорення}

Аналіз хімічних властивостей застосованих в роботі неорганічних солей $[7,8]$ показав, що при нагріванні вони розкладаються з утворенням відповідних оксидів та інших речовин, серед яких з точки зору вигоряння органічної частини мас важливими $\epsilon$ так звані «агенти-окисники» (поняття застосовано авторами). Під агентами-окисниками маються на увазі $\mathrm{O}_{2}, \mathrm{~N}_{2} \mathrm{O}, \mathrm{NO}_{2}$, які дають так званий «ефективний кисень» ([O]), що безпосередньо бере участь у реакціях згоряння.За своєю «окислювальною дією», під якою розуміється кількість утвореного [О], солі розташовуються в наступний ряд по мірі зменшення цієї діï: $\mathrm{Fe}\left(\mathrm{NO}_{3}\right)_{3} \rightarrow \mathrm{Ca}\left(\mathrm{NO}_{3}\right)_{2} \rightarrow \mathrm{K}_{2} \mathrm{Cr}_{2} \mathrm{O}_{7} \rightarrow \mathrm{NaNO}_{3}$ $\rightarrow \mathrm{KNO}_{3} \rightarrow \mathrm{NH}_{4} \mathrm{NO}_{3}$. Солі мають різні механізми утворення ефективного кисню та різні температурні інтервали розкладу з найнижчою температурою початку розкладу для $\mathrm{Fe}\left(\mathrm{NO}_{3}\right)_{3}\left(125^{\circ} \mathrm{C}\right)$ і найвищою для $\mathrm{K}_{2} \mathrm{Cr}_{2} \mathrm{O}_{7}\left(600^{\circ} \mathrm{C}\right)$.

Виходячи $з$ елементного складу відходів, горючими компонентами в них є вуглець С (29\%), водень $\mathrm{H}(2,5 \%)$, сірка $\mathrm{S}(0,5 \%)$, які можуть згоряти 3 утворенням газів $\mathrm{CO} \uparrow, \mathrm{CO}_{2} \uparrow, \mathrm{SO}_{2} \uparrow, \mathrm{H}_{2} \mathrm{O} \uparrow$. Для спрощення приймемо, що при згорянні вуглецю перебігатимуть такі взаємодії

$$
\begin{gathered}
\mathrm{C}+[\mathrm{O}] \rightarrow \mathrm{CO} \uparrow \\
\mathrm{C}+2[\mathrm{O}] \rightarrow \mathrm{CO}_{2} \uparrow
\end{gathered}
$$

Щодо інших горючих компонентів (H i S) розглядалися реакції їх окиснення до $\mathrm{H}_{2} \mathrm{O} \uparrow$ та $\mathrm{SO}_{2} \uparrow$.

Для забезпечення ефективного вигоряння паливної складової мас окисники мають бути введені у кількості, необхідній і достатній для окиснення горючих компонентів. За хімічними розрахунками кількість окисника, необхідного для згоряння горючих компонентів до газової суміші $\mathrm{CO} \uparrow+\mathrm{H}_{2} \mathrm{O} \uparrow+$ $\mathrm{SO}_{2} \uparrow$ або $\mathrm{CO}_{2} \uparrow+\mathrm{H}_{2} \mathrm{O} \uparrow+\mathrm{SO}_{2} \uparrow, \epsilon$ досить великою. Наприклад, для $\mathrm{NaNO}_{3}$ для окиснення 1 г вуглецю до $\mathrm{CO} \uparrow$ або $\mathrm{CO}_{2} \uparrow$ необхідно взяти відповідно 2,8 г та 5,7 г солі. Але в реальних умовах при випалі в газовому середовищі печі міститься якась кількість кисню, що дозволяє зменшити й кількість введеного окисника до певного рівня.

В лабораторних умовах такий рівень визначили експериментально на зразках чистих вуглевідходів, в які додавали $\mathrm{NaNO}_{3}$ в кількості від $3 \%$ до $15 \%$ від теоретичної, необхідної для повного вигоряння вуглецю з відходів. Після випалу зразків за температури $920{ }^{\circ} \mathrm{C}$ аналізували зовнішній вигляд зразків і візуально площу «чорної серцевини» в їх перетині, яка непрямо свідчить про кількість незгорілого вуглецю. Було встановлено, що всі зразки мають «чор- 
ну серцевину», при цьому площа цього дефекту по мірі зростання кількості окисника або не зменшується, або навіть збільшується (рис. 1).
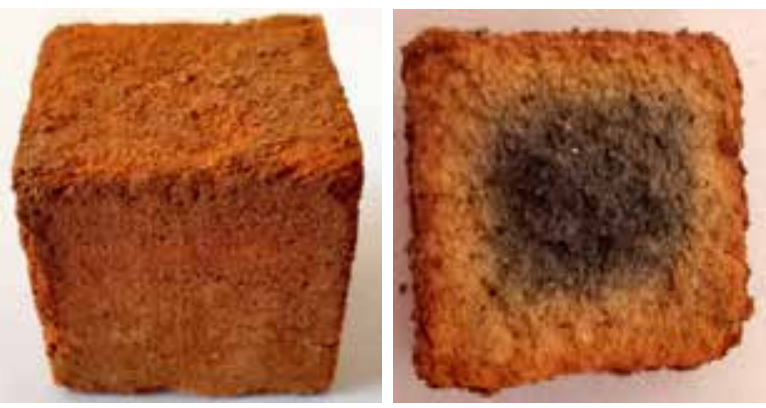

3 \% від кількості, необхідної для повного згоряння вуглецю
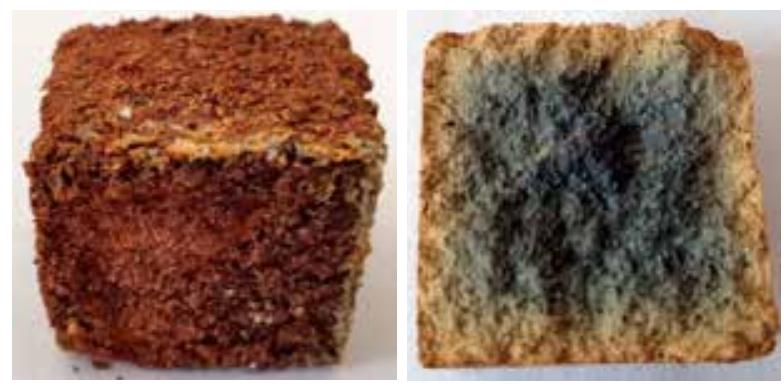

15 \% від кількості, необхідної для повного згоряння вуглецю

Рис. 1. Поверхня і перетин зразків випалених вуглевідходів $з$ добавкою $\mathrm{NaNO}_{3}$

Це може бути пов'язано $з$ тим, що натрієва селітра 3 температурою топлення $306,5^{\circ} \mathrm{C}$ чинить певну флюсуючу дію на матеріал, зокрема на його по- верхню, тому що частково кристали солі при сушці зразків виходять саме на їх поверхню. Таке припущення підтверджується тим, що поверхня зразків, на яких висоли утворилися в більшій кількості, є більш спеченою. Утворений щільний верхній шар зразка перешкоджає дифузії газів, а плавлення кристалів солі, зменшує кількість ефективного кисню, необхідного для вигоряння вуглецю. Виходячи із зовнішнього вигляду зразків випалених вуглевідходів, а також характеру впливу натрієвої селітри на процес вигоряння органіки, оптимальною кількістю цього окисника можна вважати 3 \% від теоретичної кількості.

Після встановлення оптимальної кількості добавки цього окисника був проведений розрахунок кількості так званого «еквівалентного кисню» ([О ${ }^{\text {екв}]) . ~ П і д ~ ц и м ~ р о з у м і є т ь с я ~ к и с е н ь, ~ я к и и ̆ ~ т е о р е-~}$ тично виділиться при термічному розкладі $\mathrm{NaNO}_{3}$, взятої в кількості 3 \% від необхідної для повного вигоряння вуглецю до СО $\uparrow$. Маючи значення еквівалентного кисню для $\mathrm{NaNO}_{3}$, за допомогою розробленої авторами методики хімічних розрахунків, були визначені кількості інших солей, які забезпечать таку ж саму кількість «еквівалентного кисню», необхідного для протікання реакцій окиснення вуглецю в безкисневому середовищі (табл. 1).

Для визначення впливу окисників на випалювальні властивості паливовмісних мас було розглянуто комбінацію суглинку (85 мас. \%) 3 вуглевідходами (15 мас. \%). При цьому вміст вуглецю в масі становив 4,2 \%, що при використанні природного газу забезпечує $80 \%$ його економії [9]. Окисники додавалися в масу понад 100 \% по сухій вазі в кількості, яка забезпечує задану кількість еквівалентного кисню [Оекв] (табл. 1). Після випалу за температури $950{ }^{\circ} \mathrm{C}$ (ізотермічна витримка 1 година) були

\section{Таблиця 1.}

Кількість окисників, необхідних для згоряння горючих компонентів вуглевідходів 3 утворенням газової суміші $\mathrm{CO} \uparrow+\mathrm{H}_{2} \mathrm{O} \uparrow+\mathrm{SO}_{2} \uparrow$

\begin{tabular}{|c|c|c|c|}
\hline Вид окисника & $\begin{array}{c}\text { Кількість молей ефек- } \\
\text { тивного кисню [О] при } \\
\text { розкладі окисника }\end{array}$ & $\begin{array}{c}\text { Питома витрата } \\
\text { окисника } \\
\text { (г/г відходів) }\end{array}$ & $\begin{array}{c}\text { Питома витрата окисника, що } \\
\text { забезпечує задану кількість еквіва- } \\
\text { лентного кисню [О }{ }^{\text {екв}], ~ г / г ~ в і д х о д і в ~}\end{array}$ \\
\hline $\mathrm{NaNO}_{3}$ & 2,5 & 1,257 & 0,038 \\
\hline $\mathrm{KNO}_{3}$ & 2,5 & 1,495 & 0,045 \\
\hline $\mathrm{Ca}\left(\mathrm{NO}_{3}\right)_{2}$ & 5,0 & 1,213 & 0,036 \\
\hline $\mathrm{NH}_{4} \mathrm{NO}_{3}$ & 1,0 & 2,958 & 0,089 \\
\hline $\mathrm{Fe}\left(\mathrm{NO}_{3}\right)_{3}$ & 7,5 & 1,192 & 0,036 \\
\hline $\mathrm{K}_{2} \mathrm{Cr}_{2} \mathrm{O}_{7}$ & 3,0 & 3,626 & 0,109 \\
\hline
\end{tabular}


визначені основні властивості керамічних зразків, наведені в табл. 2.

3 даних табл. 2 можна побачити, що механічна міцність зразків є значно нижче міцності чистого випаленого суглинку (20 МПа), що пояснюється значним газовиділенням при випалі зразка до початку вигоряння вуглецю $\left(500^{\circ} \mathrm{C}\right)$.

$\mathrm{B}$ той же час у порівнянні $з$ масою без добавки окисника механічна міцність зразків з їх використанням помітно вище. При цьому використання окисників в більшості випадків приводить до утворення тріщин під час випалу. Найбільша кількість тріщин спостерігається для зразків $з$ окисниками, які починають розкладатися 3 виділенням газів за відносно високих температур: $\mathrm{Ca}\left(\mathrm{NO}_{3}\right)_{2}\left(560{ }^{\circ} \mathrm{C}\right), \mathrm{NaNO}_{3}$ $\left(380{ }^{\circ} \mathrm{C}\right), \mathrm{KNO}_{3}\left(400{ }^{\circ} \mathrm{C}\right)$. За нашими припущеннями тріщиноутворення має місце за таких причин. Окисники, що розкладаються за відносно низьких температур, забезпечують більшу кількість агентів-окисників в масі.

Накопичені агенти-окисники сприяють вигорянню вуглецю і видаленню якоїсь кількості газів крізь ще не спечений, а отже й більш газопроникний черепок, що зберігає його цілісність. При використанні означених вище «високотемпературних» окисників утворення й накопичення агентів-окисників відбувається за температур, більш близьких до температур початку спікання кераміки. При цьому окиснення вуглецю відбувається на фоні утворення спеченої поверхні зразків, що накопичує гази всередині матеріалу, підвищує їх тиск і приводить до розриву зразків.

Серед досліджених солей оптимальною слід вважати $\mathrm{NH}_{4} \mathrm{NO}_{3}$ як таку, що повністю видаляється зі зразка, не утворює твердого залишку, який би знижував газопроникність матеріалу, мінімізує тріщиноутворення і забезпечує максимальну механічну міцність матеріалів при їх прийнятному зовнішньому вигляді (табл. 2).
Для розширення номенклатури використовуваних солей і покращення механічної міцності матеріалів, було розглянуто комбінації окисників, які, за нашими припущеннями, дозволили б створити у випалюваному матеріалі окислювальне середовище у більш широкому температурному інтервалі. Це посприяло б більш рівномірному протіканню процесу вигоряння вуглецю, що має покращити показники міцності.

Для перевірки цієї гіпотези було розглянуто дві комбінації окисників, які містили $80 \% \mathrm{NH}_{4} \mathrm{NO}_{3} \mathrm{i}$ $20 \% \mathrm{NaNO}_{3}$ або $\mathrm{Ca}\left(\mathrm{NO}_{3}\right)_{2}$. Загальна кількість комбінованого окисника відповідала 3 \% від теоретично необхідної для окиснення вуглецю до СО $\uparrow$. Результати аналізу міцності керамічних зразків 3 комбінованими окисниками у порівнянні з попередніми зразками (табл. 2), які отримані в таких самих умовах випалу, наведені на рис. 2.

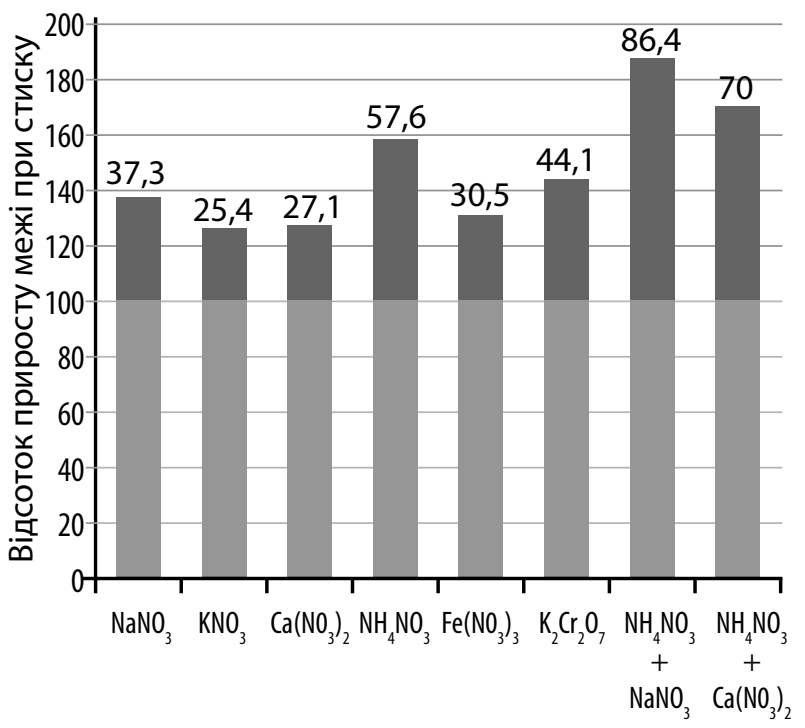

Рис. 2. Приріст механічної міцності керамічних зразків з різними окисниками

Таблиця 2

Властивості керамічних зразків, отриманих з паливовмісної маси з добавками окисників

\begin{tabular}{|c|c|c|c|}
\hline Окисник & Межа міцності при стиску, МПа & Водопоглинання, \% & Морозостійкість, цикли \\
\hline $\mathrm{NaNO}_{3}$ & 8,1 & 25,3 & 15 \\
\hline $\mathrm{KNO}_{3}$ & 7,4 & 22,7 & 15 \\
\hline $\mathrm{Ca}\left(\mathrm{NO}_{3}\right)_{2}$ & 7,5 & 22,3 & 15 \\
\hline $\mathrm{NH}_{4} \mathrm{NO}_{3}$ & 9,3 & 23,5 & 15 \\
\hline $\mathrm{Fe}\left(\mathrm{NO}_{3}\right)_{3}$ & 7,7 & 23,4 & 15 \\
\hline $\mathrm{K}_{2} \mathrm{Cr}_{2} \mathrm{O}_{7}$ & 8,5 & 22,4 & 15 \\
\hline Без добавки & 5,9 & 23,9 & 15 \\
\hline
\end{tabular}


3 рисунку можна побачити, що по відношенню до міцності матеріалів без окисників, яка прийнята за $100 \%$, найбільший приріст міцності забезпечують саме комбіновані окисники (в найбільшій мірі $\mathrm{NH}_{4} \mathrm{NO}_{3}+\mathrm{NaNO}_{3}$ ). Отже, висунута гіпотеза про розширення температурного інтервалу виділення кисню і більш рівномірне протікання процесу окиснення горючого компоненту мас при використанні комбінованих окисників знаходить своє підтвердження.

Очевидно, що більш рівномірне газовиділення і прогрівання матеріалу знижує термічні напруги, які виникають за причини неоднорідності температурного поля по перетину зразків, що в цілому приводить до їх зміцнення.

\section{Висновки}

На прикладі високовуглецевих відходів флотаційного збагачення вугілля досліджено ефективність застосування спеціальних окисників для покращення вигоряння горючого компонента вуглевідходів. Розглянуто ряд неорганічних солей, які слугують донорами кисню при випалі за рахунок утворення агентів-окисників $\left(\mathrm{O}_{2}, \mathrm{NO}_{2}, \mathrm{~N}_{2} \mathrm{O}\right)$ при їх термічному розкладі. Розрахунковим шляхом визначено, що по мірі зменшення кількості утворюваного ефективного кисню солі розташовуються в такий ряд: $\mathrm{Fe}\left(\mathrm{NO}_{3}\right)_{3} \rightarrow \mathrm{Ca}\left(\mathrm{NO}_{3}\right)_{2} \rightarrow \mathrm{K}_{2} \mathrm{Cr}_{2} \mathrm{O}_{7} \rightarrow \mathrm{NaNO}_{3} \rightarrow \mathrm{KNO}_{3}$ $\rightarrow \mathrm{NH}_{4} \mathrm{NO}_{3}$.

Експериментальним шляхом 3 використанням чистих вуглевідходів і натрієвої селітри визначена оптимальна кількість окисника (3 \% від теоретично необхідної для вигоряння вуглецю до СО $)$, яка дозволяє отримувати бездефектні зразки з максимально можливим ступенем вигоряння органічної частини.

Досліджено вплив добавок різних окисників та окремих їх комбінацій на властивості керамічних матеріалів, отриманих на основі композиції легкотопкого суглинку (85 \%) і високовуглецевих відходів флотаційного збагачення вугілля (15\%) як паливно-мінеральної добавки. Встановлено, що використання окисників приводить до покращення вигоряння вуглецевого компоненту мас і позитивно позначається на зовнішньому вигляді і механічних властивостях керамічних зразків. Найбільш ефективними виявилися комплексні добавки $\mathrm{NH}_{4} \mathrm{NO}_{3}+\mathrm{Ca}\left(\mathrm{NO}_{3}\right)_{2} \mathrm{i} \mathrm{NH}_{4} \mathrm{NO}_{3}+\mathrm{NaNO}_{3}$, що пояснюється створенням окислювального середовища у більш широкому температурному інтервалі при випалі. 3 використанням комплексних добавок отримано керамічні зразки з водопоглинанням $22 \%$ і межею міцності при стиску 10 МПа і 11 МПа відповідно, що відповідає вимогам стандарту ДСТУ Б В.2.7-61:2008 на рядову цеглу марки М100.

\section{References}

1. Agrafiotis, $C$. Energy saving technologies in the European ceramic sector: A systematic review / C. Agrafiotis, T.D. Tsoutsos Applied Thermal Engineering. 2001. - No 21 (12). - Р. 1231 - 1249.

2. Офіційний сайт Державної служби статистики України [Електронний ресурс]. Режим доступу: http://www.ukrstat.gov.ua/.

3. Офіційний сайт компанії Beralmar Technologic [Електронний ресурс]. Режим доступу: https://www. beralmar.com/en.

4. Энергетика: история, настоящее и будущее [Бондаренко В.И., Варламов Г.Б., Вольчин И.А. и др.]. - К.: ООО «Редакция «Энергетика: история, настоящее и будущее». $-2011 .-264 \mathrm{c}$.

5. Федоренко, О.Ю. Кам'яно-керамічні матеріали 3 відходів вугільної промисловості / О.Ю. Федоренко, С.М. Миколаєнко, Л.В. Руденко. Керамика: наука и жизнь. - 2011. - № 2 (12). - С. 10 - 23.

6. Система норм та правил зниження рівня іонізуючих випромінювань природних радіонуклідів в будівництві. Регламентовані радіаційні параметри. Допустимі рівні: ДБН В.1.4-1.01-97 - [Чинний від 01.01.1998]. - К.: Держкоммістобудування України. - 1997. - 12 с. - (Державні будівельні норми України).

7. Химия. Справочное руководство [Н. Keune, М. Augustin and other]; перевод с нем. Ф.Г. Гаврюченкова, М.И. Курочкиной и др. - Л.: Издательство «Химия». $-1975 .-554$ с.

8. Карякин, Ю.В. Чистые химические вещества / Ю.В. Карякин, А.А. Ангелов. - К.: Издательство «Химия». - 1974. - $406 \mathrm{c.}$

9. Цовма, В.В. Фасадні керамічні матеріали на основі сировини техногенного походження: дис. канд. техн. наук: 05.17.11. Цовма Віталій Віталійович. Харків. - 2014. - 205 с. 